UDC 621.039 .5

\title{
MATHEMATICAL RELATIONSHIPS OF MODELS OF TWO-PHASE FLOWS IN CHANNELS OF REACTORS AND STEAM GENERATORS OF NPP's FOR CALCULATION OF THEIR HYDRODYNAMIC CHARACTERISTICS
}

\author{
O.V. Yefimov ${ }^{I}$, M.M. Pylypenko ${ }^{2}$, V.L. Kavertsev ${ }^{1}$, T.A. Harkusha ${ }^{1}$, T.O. Yesypenko ${ }^{I}$ \\ ${ }^{1}$ National Technical University "Kharkiv Polytechnic Institute", Kharkiv, Ukraine \\ E-mail: AVEfimov@kpi.kharkov.ua; \\ ${ }^{2}$ National Science Center "Kharkov Institute of Physics and Technology”, Kharkiv, Ukraine
}

Two-phase flows of the working substance in the steam-generating channels of reactors of single-circuit NPP's and steam generators of two- and three-circuit NPP's represent the joint movement of liquid (feed water) and steam in the form of a steam-water mixture. The forms of movement of two-phase flows are much more diverse, and the laws of their movement are much more complicated than flows of single-phase media, and they are characterized by a large number of parameters. This is due to the fact that when the flow of the steam-water mixture moves in the steam-generating channels, mass exchange processes occur between the liquid and vapor phases of the mixture, in which the volumes of the phases change; the interfaces between the phases of the mixture vary along the length of the channel and often do not have a distinct character. The cross-sectional mean velocities of the liquid and vapor phases of the flow are not equal to each other, and the difference in the velocities of the phases in the steady-state mode of motion of the two-phase flow depends on the mass flow rate of the steam-water mixture, its pressure, direction of flow, heating intensity, and other indicators. All this complicates experimental studies and calculations of parameters and hydrodynamic (gas-dynamic) characteristics of two-phase flows of a steam-water mixture of a working substance in reactors and steam generators of nuclear power plants. The article discusses mathematical relationships for calculating the hydraulic characteristics of two-phase flows of different structures during the movement of a steam-water mixture in the steam-generating channels of reactors and steam generators of nuclear power plants, namely bubble, slug, rod, dispersed. The ratios are given for various designs of the channels of reactors and steam generators.

\section{INTRODUCTION}

Two-phase flows of the working substance in the steam-generating channels of reactors of single-circuit NPP's and steam generators of two- and three-circuit NPP's are a combined movement of liquid (feed water) and steam in the form of a steam-water mixture [1-3].

The forms of motion of two-phase flows are much more diverse, and the laws of their motion are much more complex than the flows of single-phase media, and they are characterized by a large number of parameters.

This is due to the fact that when the flow of the steam-water mixture moves in the steam-generating channels, mass exchange processes occur between the liquid and vapor phases of the mixture, in which the volumes of the phases change; the interfaces between the phases of the mixture vary along the length of the channel and often do not have a distinct character. The cross-sectional mean velocities of the liquid and vapor phases of the flow are not equal to each other, and the difference in the velocities of the phases in the steadystate mode of motion of the two-phase flow depends on the mass flow rate of the steam-water mixture, its pressure, direction of flow, heating intensity, and other indicators. All this complicates experimental studies and calculations of parameters and hydrodynamic (gasdynamic) characteristics of two-phase flows of a steamwater mixture of a working substance in reactors and steam generators of nuclear power plants [4-8].

\section{PROBLEM STATEMENT}

The main ratios for determining the mass consumption of the steam-water mixture $D_{\Sigma}$ in the area of the steam-generating channel, the consumption of its steam and water phases $D_{S}$ and $D_{W}$, the mass (consumable) steam city $x$ when entering the channel of the mass of nutrient water $D_{0}$ is the equation for preserving the amount of substance in the stream and the equation of the heat balance for the area of the calculated channel.

The equation for preserving the amount of substance in the stream is as follows:

$$
D_{0}=D_{S}+D_{W}=D_{\Sigma} .
$$

The heat balance equation for the calculated section of the steam generating channel, schematically shown in Figure, can be written as

$$
D_{\Sigma}\left(i-i^{\prime}\right)=q_{l}\left(l-l_{b . b}\right),
$$

where $i, i^{\prime}$ - respectively, the enthalpy of the steamwater mixture in the cross section at the outlet of the calculated section of the channel and the enthalpy of the feed water in the cross section of the beginning of its boiling, $\mathrm{J} / \mathrm{kg} ; l, l_{b . b}-$ respectively, the length of the entire section of the channel and the length of the section of the channel to the cross section of the beginning of boiling of feed water, $\mathrm{m} ; q_{l}-$ average specific heat flux in the channel section, $\mathrm{W} / \mathrm{m}$.

The enthalpy of the steam-water mixture is determined from the equation (3) 


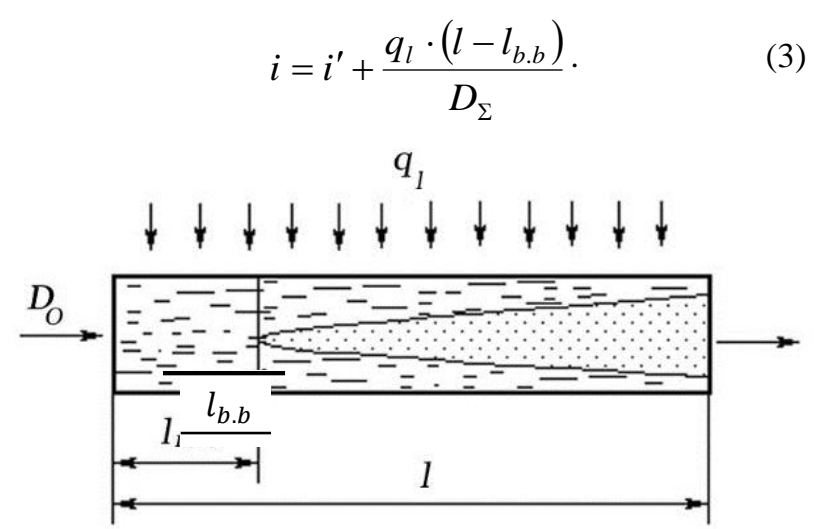

Scheme of the steam generating channel

The amount of heat $q_{\Sigma}$ transferred by the steam-water mixture through the calculated cross section of the steam-generating channel per unit time is $q_{\Sigma}=D_{\Sigma} \cdot i$; the amount of heat $q_{w}$, transferred by the aqueous phase of the mixture through the calculated cross section of the steam generating channel per unit time, is $q_{w}=D_{w} \cdot i^{\prime}$; the amount of heat $q_{s}$, transferred by the vapor phase of the mixture through the calculated cross section of the steam generating channel per unit time, is $q_{s}=D_{s} \cdot\left(i^{\prime}+r\right)$, where $r-$ latent specific heat of vaporization, $\mathrm{J} / \mathrm{kg}$.

The ratio between the enthalpies of the two-phase flow of the steam-water mixture and its water and steam phases is as follows:

$$
D_{\Sigma} \cdot i=D_{W} \cdot i^{\prime}+D_{S}\left(i^{\prime}+r\right) .
$$

The ratio of the mass of the vapor phase of the steam-water mixture to the total mass of the entire twophase flow is called the mass (flow) vapor content:

$$
x=\frac{D_{s}}{D_{s}+D_{w}}=\frac{D_{s}}{D_{0}} .
$$

Dividing equation (4) by $D_{\Sigma}=D_{0}$ and taking into account equation (5), we obtain the ratio for calculating the mass vapor content in the cross section of the section of the vapor channel, which is determined by:

$$
i=\frac{\left(D_{s}+D_{w}\right) \cdot i^{\prime}}{D_{0}}+\frac{r D_{s}}{D_{0}}=i^{\prime}+r x
$$

or

$$
x=\frac{i-i^{\prime}}{r} .
$$

The value $x$ in equations (6) is the relative enthalpy of the two-phase flow, expressed through the latent specific heat of vaporization, which characterizes the flow rate in the cross section of the calculated section of the channel after the start of boiling feed water.

Mass characteristics of two-phase flows (phase masses, their ratio), as well as the amount transferred by flows and their heat phases, are the initial data for calculating the basic parameters and hydrodynamic (gas-dynamic) characteristics of two-phase flows of steam-water mixture in steam generating channels of reactors and steam generators .

The main parameters of the two-phase flows of the steam-water mixture belong to the reduced velocities of the vapor phase $w_{0}^{\prime \prime}$ and the water phase $w_{0}^{\prime}$, as well as the speed of circulation of the vapor-water mixture $w_{0}$. The given velocities are the ratio of the volume flow rate of each phase to the area of the full cross-section of the channel. The velocity of the steam-water mixture is the speed that water would have in a given cross-section if it passed through it with a mass flow rate equal to the flow rate of the steam-water mixture. These parameters are calculated by the following ratios:

$$
w_{0}^{\prime \prime}=\frac{D_{s} v^{\prime \prime}}{f} ; w_{0}^{\prime}=\frac{D_{w} v^{\prime}}{f} ; w_{0}=\frac{D_{\Sigma} v^{\prime}}{f},
$$

where $v^{\prime \prime}$ and $v^{\prime}$ - respectively, the specific volumes of steam and water at saturation temperature $t_{s}, \mathrm{~m}^{3} / \mathrm{kg}$; $f$ - the cross-sectional area of the steam-generating channel, $\mathrm{m}^{2}$.

From equations (7) it is seen that at a constant flow of feed water $D_{0}\left(D_{0}=D_{\Sigma}\right)$ and at a constant crosssectional area of the channel $f$ circulation speed $w_{0}$ is a constant value, and the reduced velocities of the vapor and water phases of the flow $w_{0}^{\prime \prime}$ and $w_{0}^{\prime}$ vary depending on the mass flow rate of the phases.

The mass vapor content in equation (5) can be determined using relation (7):

$$
x=\frac{D_{s}}{D_{0}}=\frac{w_{0}^{\prime \prime} \rho^{\prime \prime}}{w_{0} \rho^{\prime}}=\frac{w_{0}^{\prime \prime} v^{\prime}}{w_{0} v^{\prime \prime}},
$$

where $\rho^{\prime \prime}, \rho^{\prime}$ - respectively, the density of the vapor and water phases of the flow.

From the equation of conservation of the amount of substance in the stream (2) with a constant crosssectional area of the channel $f=$ const we obtain the ratio between the reduced phase velocities and the circulation rate:

$$
w_{0} \rho^{\prime}=w_{0}^{\prime} \rho^{\prime}+w_{0}^{\prime \prime} \rho^{\prime \prime}=w_{\Sigma} \rho_{\Sigma}=\text { const }
$$

or

$$
w_{0}=w_{0}^{\prime}+w_{0}^{\prime \prime} \frac{\rho}{\rho^{\prime \prime}} .
$$

The volumetric flow rates of the vapor phase $V_{s}$ and the water phase $V_{w}$ of the two-phase flow are determined by the ratios:

$$
V_{s}=\frac{D_{s}}{\rho^{\prime \prime}}, \quad V_{w}=\frac{D_{w}}{\rho^{\prime}} .
$$

Using relation (7), the volumetric flow rates of the phases can be determined through the following velocities:

$$
V_{s}=w_{0}^{\prime \prime} f ; \quad V_{w}=w_{0}^{\prime} f .
$$

If the cross-sectional areas of the steam and water phases of the two-phase flow are known $f_{s}$ and $f_{w}$, it is possible to determine the average cross-sectional actual velocities of the steam phase $w_{s}$ and the water phase $w_{w}$ by the equations:

$$
w_{s}=\frac{V_{s}}{f_{s}}=w_{0}^{\prime \prime} \frac{f}{f_{s}}, w_{w}=\frac{V_{w}}{f_{w}}=w_{0}^{\prime} \frac{f}{\left(f-f_{s}\right)},
$$
where $f=f_{s}+f_{w}$.

The average actual velocities of the vapor and water phases are not equal to each other, and the difference in these velocities is greater the greater the difference in density between the phases. 
The fraction of the cross-sectional area of the channel occupied by the vapor phase of the two-phase flow is

$$
\varphi=\frac{f_{s}}{f} .
$$

The value of $\varphi$ also allows you to determine the average actual phase velocities by the formulas:

$$
w_{s}=\frac{w_{0}^{\prime \prime}}{\varphi} ; \quad w_{w}=\frac{w_{0}^{\prime}}{1-\varphi} .
$$

Hence,

$$
\varphi=\frac{w_{0}^{\prime \prime}}{w_{s}} ; \quad \varphi=1-\frac{w_{0}^{\prime}}{w_{w}} .
$$

The mass of the steam-water mixture in the lifting steam-generating channel height is determined by the following equation:

$$
\rho_{\Sigma} \cdot \Delta l \cdot f=\rho^{\prime \prime} \cdot \Delta l \cdot f_{s}+\rho^{\prime} \cdot \Delta l \cdot f_{w},
$$

where $\rho_{\Sigma}-$ the actual density of the steam-water mixture.

To determine the true density of the steam-water mixture after a series of transformations of formula (17), we can obtain equation

$$
\rho_{\Sigma}=\rho^{\prime}-\varphi\left(\rho^{\prime}-\rho^{\prime \prime}\right) \text {. }
$$

Given expressions (16) and (18), from equation (9) we obtain the calculation formula for determining the actual velocity of the steam-water mixture:

$$
w_{\Sigma}=\frac{w_{0} \rho^{\prime}}{\rho^{\prime}-\varphi\left(\rho^{\prime}-\rho^{\prime \prime}\right)}=\frac{w_{0}}{1-\varphi\left(1-\frac{\rho^{\prime \prime}}{\rho^{\prime}}\right)} .
$$

The fraction of the cross-sectional area of the steamgenerating channel, which is occupied by the vapor phase of the two-phase flow of the working substance, uniquely determines the average values of the phase velocities, the actual velocity of the mixture and its density. Therefore, it is often called the actual vapor content of the vapor-water mixture (as opposed to mass vapor content $x$ ). This value primarily depends on the sliding speeds of the phases, which, in turn, depend not only on the parameters and direction of flow, but also on the distribution of steam and water phases in the volume of the channel. At this time, the most accurate actual vapor content is determined only experimentally.

\section{CONCLUSIONS}

The given mathematical relations for calculation of hydraulic characteristics of two-phase flows in channels of reactors and NPP steam generators are suitable for creation of models of processes in steam-generating channels of various constructive executions and can be used in decision support systems at their designing.

\section{REFERENCES}

1. P.L. Kirillov, Yu.G. Yuriev, V.P. Bobkov. Handbook of thermohydraulic calculations (nuclear reactors, heat exchangers, steam generators). M.: "Energoatomizdat", 1990, 358 p.

2. A.I. Clemin, L.N. Polyanin, M.M. Strigulin. Teplohydraulic calculation and thermotechnical reliability of nuclear reactors. M.: "Atomizdat", 1980, $261 \mathrm{p}$.

3. O.V. Yefimov, M.M. Pylypenko, T.V. Potanina, V.L. Kavertsev, T.A. Harkusha. Reactors and steam generators of NPP power units: schemes, processes, materials, structures, models. Kharkiv: LTD "Infact", 2017, 420 p.

4. O.V. Yefimov, D.I. Kuhtin, T.V. Potanina, T.A. Harkusha, V.L. Kavertsev. Automated decision support system by operational personnel of NPP power units according to the criterion of technical and economic efficiency taking into account reliability indicators // Nuclear and radiation safety. 2018, N 2(78), p. 11-19.

5. O. Yefimov, M. Pylypenko, T. Potanina. Materials and decision support systems in the nuclear power industry: Monography. LAP Lambert Academic Publishing, Riga, Latvia, 2020, 135 p.

6. Т.В. Потанина, А.В. Ефимов, Т.А. Гаркуша, Т.А. Есипенко. Применение методов интервального анализа для оценки безопасности и надежности энергоблоков АЭС // Ядерна та радіаційна безпека. 2018, №3(79), c. 23-29.

7. A.V. Yefimov, T.V. Potanina. Application of interval analysis for improving reliability of hardness value spread for nuclear structural materials // Problems of Atomic Science and Technology. 2020, N 1(125), p. 206-210.

8. O.V. Yefimov, M.M. Pylypenko, T.V. Potanina, T.A. Yesypenko, V.L. Kavertsev, T.A. Harkusha. Components of the automated intellectual systems supporting decisions at the stage of operation and equipment diagnostics nuclear power units // Problems of Atomic Science and Technology. 2020, N 1(125), p. $127-134$.

\title{
МАТЕМАТИЧЕСКИЕ СООТНОШЕНИЯ МОДЕЛЕЙ ДВУХФАЗНЫХ ПОТОКОВ В КАНАЛАХ РЕАКТОРОВ И ПАРОГЕНЕРАТОРОВ АЭС ДЛЯ РАСЧЕТА ИХ ГИДРОДИНАМИЧЕСКИХ ХАРАКТЕРИСТИК
}

\author{
А.В. Ефимов, Н.Н. Пилипенко, В.Л. Каверцев, Т.А. Гаркуша, Т.А. Есипенко
}

Двухфазные потоки рабочего вещества в парогенерирующих каналах реакторов одноконтурных АЭС и парогенераторов двух- и трехконтурных АЭС представляют собой совместное движение жидкости (питательной воды) и пара в виде пароводяной смеси. Формы движения двухфазных потоков значительно разнообразнее, а законы их движения гораздо сложнее, чем потоков однофазных сред, и характеризуются они большим количеством параметров. Это обусловлено тем, что при движении потока пароводяной смеси в парогенерирующих каналах происходят массообменные процессы между жидкой и паровой фазами смеси, при которых изменяются объемы фаз; границы раздела между фазами смеси меняются по длине канала и 
часто не имеют четко выраженного характера. Средние по сечению скорости жидкой и паровой фаз потока не равны между собой, причем отличие в скоростях фаз при установившемся режиме движения двухфазного потока зависит от массового расхода пароводяной смеси, ее давления, направления движения потока, интенсивности нагрева и других показателей. Все это затрудняет экспериментальные исследования и расчеты параметров и гидродинамических (газодинамических) характеристик двухфазных потоков пароводяной смеси рабочего вещества в реакторах и парогенераторах АЭС. В статье рассмотрены математические соотношения для расчета гидравлических характеристик двухфазных потоков разной структуры при движении пароводяной смеси в парогенерирующих каналах реакторов и парогенераторов АЭС, а именно пузырькового, снарядного, стержневого, дисперсного. Соотношения приведены для различного конструктивного исполнения каналов реакторов и парогенераторов.

\section{МАТЕМАТИЧНІ СПІВВІДНОШЕННЯ МОДЕЛЕЙ ДВОФАЗНИХ ПОТОКІВ У КАНАЛАХ РЕАКТОРІВ І ПАРОГЕНЕРАТОРІВ АЕС ДЛЯ РОЗРАХУНКУ ЇХ ГІДРОДИНАМІЧНИХ ХАРАКТЕРИСТИК}

\section{О.В. Сфімов, М.М. Пилипенко, В.Л. Каверцев, Т.А. Гаркуша, Т.О. Ссипенко}

Двофазні потоки робочої речовини в парогенеруючих каналах реакторів одноконтурних АЕС i парогенераторів дво- і триконтурних АЕС являють собою сумісний рух рідини (живильної води) і пари у вигляді пароводяної суміші. Форми руху двофазних потоків значно різноманітніші, а закони їх руху істотно складніші, ніж потоків однофазних середовищ і характеризуються вони великою кількістю параметрів. Це обумовлено тим, що при русі потоку пароводяної суміші в парогенеруючих каналах відбуваються процеси масообміну між рідкою і паровою фазами суміші, при яких змінюються об'єми фаз; межі розділу між фазами суміші змінюються по довжині каналу і часто не мають чітко вираженого характеру. Середні по перерізу швидкості рідкої і парової фаз потоку не рівні між собою, причому відмінність в швидкостях фаз при сталому режимі руху двофазного потоку залежить від масової витрати пароводяної суміші, іï тиску, напряму руху потоку, інтенсивності нагріву і інших чинників. Все це ускладнює експериментальні дослідження i розрахунки параметрів і гідродинамічних (газодинамічних) характеристик двофазних потоків пароводяної суміші робочої речовини в реакторах i парогенераторах АЕС. У статті розглянуті математичні співвідношення для розрахунку гідравлічних характеристик двофазних потоків різної структури при русі пароводяної суміші в парогенеруючих каналах реакторів і парогенераторів АЕС, зокрема бульбашкового, снарядного, стрижневого, дисперсного. Співвідношення наведені для різного конструктивного виконання каналів реакторів і парогенераторів. 